\title{
The damage done by big data-driven public relations
}

\author{
Professor Anne Gregory* \\ Professor of Corporate Communication \\ University of Huddersfield \\ Professor Gregor Halff \\ Dean \\ Copenhagen Business School
}

\author{
* Corresponding author \\ Huddersfield Business School \\ University of Huddersfield \\ Firth Street \\ Huddersfield \\ HD1 3EH \\ United Kingdom \\ Tel: +44(0)1484 473996 \\ Mobile: $+44(0) 7583071338$ \\ Email: a.gregory@hud.ac.uk
}




\section{ABSTRACT}

\section{The damage done by big data-driven public relations}

Over the last two decades it has been argued that public relations contributes to hegemony by corporate organizations over stakeholder groups who have less power and resources. In its original formulation, the concept of hegemony had two defining features: firstly, it was conceived of as a society-wide, macroscopic formation and second as self-reinforcing i.e. self-replicating.

This article argues that the rise of big-data in public relations is a hegemonic development that further re-enforces the current institutional logics and power in the three main spheres of society: corporate, governance and civic. Using the economic notion of externalities, the authors argue that loss of agency over personal data is the unpriced, unrecognized externality that drives the big-data market. This externality is dependent on those who are the losers of agency not having the requisite information, power or resources to negotiate alternatives that might re-dress the balance. As users and proponents of the use of big data, the public relations profession has a number of key questions to answer if it is not to re-inforce arguments that it is a hegemonizing force in organizations and society and these are of both an economic and ethical nature.

Normal economic remedies to address externalities are not adequate to a case that is both ethical as well as economic in nature. The article therefore concludes with five arguments that the public relations profession should debate to provide leadership within organisations and society in addressing the issues raised.

Key words: hegemony, big data, externalities, ethics Highlights:

- Big data in public relations is a hegemonic development

- It reinforces the current institutional logics of the three main spheres of society: corporate, governance and civic which appears unquestioned 
- The economic notion of externalities conceptualizes the main issue: the loss of agency over personal data

- The data supplier is disempowered and uncompensated for this loss of agency

- The data collector and aggregator is empowered and financially enriched

- A debate is required which poses ethical and potential economic redress for those yielding their data

- Five key strands for this debate are proposed 


\section{The damage done by big data-driven public relations}

The argument that public relations ultimately contributes to hegemony by corporate organizations and by managerial logic over stakeholder groups not similarly constituted, has been well laid out, especially in the first decade of this century. At the core of the (then emergent) research agenda was the identification of public relations as a 'hegemonic practice' that - while purporting to engage in dialogue, symmetry, and consensus-building, chiefly seeks to 'legitimize the perspectives and actions of the corporate manager' and thus secures the organization remaining more powerful than its stakeholders and publics. (Holtzhausen, 2002: 251). Using the lens of hegemony, some mostly postmodern and critical authors, (e.g., Holtzhausen 2000, 2002; L'Etang 2005; L'Etang \& Piezcka, 1996, 2005; Roper, 2005) developed an alternative perspective. This differed not just from the otherwise mostly functionalist public relations academy (Argenti, 2013; Cornelissen, 2017), but also opposed the dominant preferred self-identity in the public relations industry as a genuine, largely benign management function whose main problem was that it was yet to be universally recognized as such.

A central concept of the critical understanding of public relations - that of hegemony - has not been fully developed. Holtzhausen (2002) called for a revival of Gramsci's (1971) understanding of hegemony, but few (e.g., Palenchar et al. 2017; Roper, 2005) seem to have fully appreciated that this particular concept of hegemony is firstly meant as a society-wide, macroscopic formation (and not simply a management-technique) and secondly as self-reinforcing, i.e., hegemony has consequences that in turn replicate the hegemony. Less scholarly observers seem to have realized this better, as shown in the popular book on the public relations industry 'Toxic sludge is good for you!' (Stauber \& Rampton, 1995) and when The Economist (16 December 2010) wrote that 'PR man [sic] has conquered the world - he still isn't satisfied'.

The authors of this article contend that the scholarly attention to hegemonic structures in public relations needs to be revived and that this revival is as 
necessary as ever for a critical reflection of public relations due to the rise of big data. Refocussing on hegemony through public relations has become urgent in modern life that is not only being enabled through technology, but transacted through it (Polonski 2016). Whether they be social, financial, political or informational, transactions are increasingly being conducted online. In many instances there is no choice: from booking and buying airline seats to donating to charities, to submitting tax returns, online is the sole method of transaction. Various accounts of life lived off-line demonstrate both rewards, but also a sense of disenfranchisement and worthlessness (BritainThinks 2015; Suresh 2016). In these accounts there is agreement that it is becoming more difficult to live a life totally offline. Human agency is being profoundly affected by the hegemonic nature of technology (Bourne, 2019).

This hegemonic nature has particular relevance for public relations where big data repositories are fast becoming the production input for stakeholder management. The public relations academy is already rich with inquiry about the use of online transactions and big data in public relations activity (Annenberg, 2019; Galloway \& Swiatek, 2018; Wiesenberg et al., 2017; Weiner \& Kochar, 2016). Missing from the public relations academy's inquiry is, however, a macroscopic (as opposed to organizational) perspective in which the costs of such modern-day forms of hegemony can be explained. This article attempts to fill that gap by drawing on economic theory of a macroscopic nature and by describing the cost of hegemony not only to an organization's stakeholders, but to markets and societies as a whole. Specifically, the concept of externalities is drawn from economics (Barnett \& Yandle, 2009; Rothschild \& Stiglitz, 1976; Van den Bergh, 2010, 2012) and applied to understand the costs of big data in public relations in the corporate, governance and civic (Friedland \& Alford, 1991) spheres of society. Following which, remedies are developed for the costs thus identified. In summary, this paper will claim that it is the duty of public relations to surface the societal debate around the hegemonic nature of big data-driven public relations and act as the guardian of those stakeholders who are potentially most affected by the damage it does. 


\section{Public relations and big data}

Put simply, two types of transactions create big data. First, an individual will transact with a specific entity to obtain an item whether that be a product, a service or information. Second, information about individuals' and organisations' business transactions and from other online activity, is available for third-party commercial organisations who specialize in data collection to 'scrape' and trade. Every transaction online leaves a trace that third parties with the requisite expertise and resources can obtain using freely available online tools such as Facebook Ads Manager, which aggregates data from Facebook, Instagram and WhatsApp. As described by Nunan and Di Domenico (2017, p. 483), the resulting value lies in "large scale analysis of data, not just collection, and the combination of multiple datasets [...] Not so much the size of the data is big, but "the capacity to search, aggregate and analyse large datasets".

Some specialist organisations, such as the now infamous Cambridge Analytica which drew controversial attention to itself for its work on voter profiling in political campaigns globally, including the UK BREXIT campaign and in aid of Donald Trump's election to the US Presidency (see https://www.bbc.co.uk/news/world-43476762), have gone one step further. They trade scraped information on individuals which can then be put together with psychological profiling. "The team had amassed, on average, 5000 data points about the behavioural trends of American citizens [...]. These had been purchased - entirely legally - from technology companies" (Tett, 2017) and were used to develop a range of voter psychological profiles which had significant influence on voting results (see https://www.youtube.com/watch?v=lBgHrnTrD8).

Value from big data is therefore obtained from being able to "derive meaning, recognize patterns, and make informed assumptions in decision-making" (Weiner \& Kochar, 2016). The ability to create such value is likely to be already hegemonically distributed: huge resources may be needed to be able to exploit the potential of big data and these will be more readily at the command of those who have the money and access to talent to devote to it (Bourne, 2019; Collister, 
2015; CVollisterest, 2019). Moreover, the big data market reproduces its own hegemony: the marginal cost of storing additional data are minimal, while the additional value rises as there is yet more ability to generate and analyze online transactions with individuals. Furthermore, data-supplying individuals while seemingly paying for one, exlusive transaction with their data, are actually sellers of goods in a wide, non-exclusive market with no price paid to them, but with great value to the organization retaining their data (West, 2019). The resulting lack of agency over their own data (and its subsequent use) is the real, but hidden cost of the transaction. Thus, the aggregation of data not only creates value for some, it also creates and perpetuates the hegemony of the dataaggregating parties over data- supplying individuals:

Public relations is both a producer as well as a main beneficiary of such hegemony (Weiner \& Kochar, 2016), especially through descriptive as well as predictive data mining, a market that is set to grow from $\$ 4.5$ in 2014 to $\$ 274.3$ billion in 2022 (IDC, 2019). Predictive mining makes inferences based on the data to predict what stakeholder groups may do in future. To do so, algorithms are programmed for which the many in-built biases and issues of transparency have been raised in earlier research (Buhmann, Passman \& Fieseler, 2019; Cerquitelli, Quercia \& Pasquale, 2017; Flyverbom, Deibert \& Matten, 2019; Lepri, Letouze, Pentland, \& Vinck, 2017). In particular, algorithms create agency for organizations conducting public relations (Collister, 2015) while the agency of individuals and stakeholder groups over their own data drops to nearly nil.

It should be stated at this juncture that public relations is not the only communicative function to benefit. For example, marketing and political campaigning are in the same privileged position, as are those new kinds of organisations who specialize in data aggregation and analysis such as Cambridge Analytica. It should also be stated that not all public relations functions and practices are designed or seek to reinforce hegemony. There are many examples of deliberative discourses such as appreciative enquiry and citizen juries which aim to empower community decision-making, for example over local police budgets and urban design. 
However, there is a pervasive narrative and almost pathological optimism (Bourne, 2019) in public relations about embracing these data transaction structures to release practitioners from the drudgery of the routine and to 'do management', or 'strategic' work instead, thus moving closer to the long-elusive status of a strategic management function (Buhmann et al. , 2019; Galloway \& Swiatek, 2018, Wiesenberg et al., 2017; Weiner \& Kochar, 2016). Indeed, some practitioner think tanks are advocating that public relations wholeheartedly adopt intelligence gathering and 'objective' data to help demonstrate business value. There is a relentlessness in the discourse about how these transactions enable the profession to prove business value (AW Page Society, 2019; Weiner \& Kochar, 2016). That narrative is as hegemonic as the desire to be a management function has long been portrayed to be. In the current narrative, big data is not expected to empower stakeholders, as critiqued by Holtzhausen (2016), but instead to reproduce hegemony over them as described above.

The authors of this article posit that this hegemony, at the expense of stakeholders' agency, can best be understood using the economic concept of 'externality', i.e. the positive or negative consequences that are produced by a specific transaction, a field of transactions or an entire market, but for which the costs are not borne by all of the participants of the transaction and are therefore not included in the pricing system (Akerlof 1970, 2000; Spence 2002; Stiglitz 1975).

\section{Externalities.}

Information-based economic theories incorporate societal conditions under which the economy works (or does not). Two of these information-based paradigms, both awarded Nobel Prizes, are at the core of current economic debate: 'information asymmetry', as advanced by Akerlof (2000), Spence (2000), and Stiglitz $(1975,2000)$ and 'common-pool resources', as described by Ostrom (1990). This paper uses the first of these two as the authors' goal is to conceptualize flaws of and damage by a market (of big data), while Ostrom's 
achievement has been to identify the information-sharing and governance principles with which, in some markets and under specific circumstances, such damage can be avoided or reversed.

As described in economic theories of information asymmetry, externalities are a "cost or benefit imposed on or provided to others but not taken into account by economic agents who generate the effect" (Barnett and Yandle 2009, p. 130). Buyers and sellers agree on prices that are too low if they do not incorporate negative externalities (like traffic congestion) or too high if positive externalities (like public health care services for a firm's employees) are unknown or ignored. While (neo)classical economic theorists mostly exclude these externalities from their analyses and assume that they will over time be included in the price system, more current theorists posit not only that the price system is incapable of reflecting externalities, but also that market participants are constantly at risk of remaining unaware of these external costs, thus making them more likely to persist, .i.e., the price of a good will remain too low and it becomes more unlikely for a market to produce outcomes to society's benefit (Spence 2012).

Externalities are therefore enabled and indeed embraced by some market participants while others remain unaware of them, especially if the former also have control over the dominant narrative about that market. In addition, one party of a transaction will have more information about it than the other, mostly because some information is too costly to get, relative to its benefit (Rothschild \& Stiglitz, 1976; Spence 2012). Those parties having more information are likely to be significantly advantaged. All this seems to be precisely the case for big datadriven public relations. The cost of getting and exchanging information may have shrunk, but the rise of on-line transactions has not made information asymmetries obsolete (Spence, 2002; Naim, 2013).

Like all externalities, that of data-driven public relations, loss of agency for stakeholders, is unpriced because there is insufficient information about it outside of those benefitting. Stakeholders are insufficiently aware of the negative externality and of the low price they are being paid for their data; they 
consequently have given up the option of transacting more selectively or of simply withholding their data altogether (Rothschild \& Stiglitz, 1976). Even if a person expressly negotiated to sell their personal data to a data-aggregating company, they may not be aware of how it is going to be used, for example, to influence elections (Doward \& Gibbs, 2017) and in a way in which they would not approve. Importantly, the increase in hegemony (through public relations practices) and the decrease of agency (of stakeholders) is not so much the anomaly of big data-driven public relations, but its essence: the asymmetry is reproduced with every transaction and is thus a self-replicating hegemonic structure.

Economic theory would expect such an imbalanced market to collapse once participants become aware of the disadvantage that they incur in any transaction with a hegemonic organization. This has first been described by Akerlof (1970) as a 'market for lemons': when one party becomes wary of hidden costly externalities, they will only selectively commit resources (in this case: personal data), thus damaging even well-intentioned practitioners of big data-driven public relations who will next tend to withdraw from the market altogether and thus leave it dominated by those who deserve wariness in the first place.

The collapse of hegemonic practices in data-driven public relations is, however, not happening. Information asymmetries prevent individual data-suppliers from becoming aware of the main externality (the loss of their agency) and from subsequently becoming far more selective in the personal data they supply. In addition, even if data-suppliers did wish to withhold information, their practical ability to do so is usually severely limited - for example individuals refusing to accept a cookie request, or to complete a data field normally find the transaction they embarked upon stalled at that instant.

\section{Hegemony in corporate, governance and civic spheres.}

Big data extends, as popularised in Harvard Business Review (McAffee \& Brynjolfsson, 2012; Nunan \& DiDomenico, 2017), to commercial, public and governmental spheres. This is precisely in line with Gramsci's understanding of 
hegemony as extending from the economic sphere to the civil and the government spheres (Roper, 2005).

In their seminal paper on institutional logics, Friedland and Alford (1991) identify political democracy, capitalism and state bureaucracy as the three institutional spheres in society. They all have their own 'institutional logics', i.e., overarching rationales that justify actions within a sphere. The authors of this article similarly suggest that there are three recognisable and definable spheres affected by big data-driven public relations. Those dominated by corporate interests, (corporate sphere), by the government (governance sphere), and by civil society (civic sphere), whose institutional logics, the authors contend, are profitability, power and participation, respectively (Friedland \& Alford 1991, p. 248; Thornton \& Ocasio, 2009). Taking these spheres in turn, it is possible to better understand the externalities of big data-driven public relations: the decrease in agency for individuals and the simultaneous increase of hegemonic structures in each which is driven by the dominant players.

\subsection{The corporate sphere}

As has been noted earlier, although it is technically possible not to engage in online transactions, it is increasingly difficult, especially in the area of the provision of goods and services. Indeed, there are an increasing number of organisations whose goods and services can only be obtained online (e.g. Amazon, Uber, some airlines) and traditional organisational forms are being challenged in almost every sector from banking to hotel booking to grocery shopping, as platformbased businesses become more ubiquitous. According to the Centre for Retail Research (2019), e-commerce is the fastest growing retail market in Europe and North America. Online retail merchandise sales in Western Europe grew from $£ 152.20$ bn in 2015 and are expected to reach $£ 249.00$ bn in 2020

In the corporate sphere the monetisation of data freely given by consumers to data aggregators (often aligned with an inability of those supplying that data to opt out) means that those consumers are not able to profit from the data that they themselves supply. Not only are they unable to negotiate the sale of their 
personal data to organisations, but their participation in 'profit' (the institutional logic of the corporate sphere) is being diminished. This is especially true if companies do not use data that are actually relevant to a transaction but instead resort to using proxy data. So, for example, it is quite common for those people who belong within a particular zip-code to be characterized as being identical by an algorithm: the zip code is a proxy for the person. These proxies can damage the ability of consumers to access the institutional logic of the corporate sphere when used indiscriminately, for example, when a zipcode leads to a poorer credit rating, or when assumptions are made about educational achievement, or when activity on LinkedIn is aggregated and sold to employers as a forecast of when and which employees are at risk of leaving for another job (Bloomberg Businessweek, 20 November 2017). In short, it becomes more costly for the individual to take part in the institutional logic of the corporate sphere.

\subsection{The Governance sphere}

In the governance sphere the loss of agency produced by big data-driven public relations can limit access to power, which is this sphere's institutional logic. Unequal access to power is already inherent to any governance sphere, but it is being reinforced and reproduced by the data transactions in the communication between a citizen and government: these cannot be reversed (by either, but importantly not by the citizen).

Given that governments already have a necessary level of coercive power over citizens though regulation, legislation and taxation, their availability to access and indeed require more personal data may create an even greater imbalance in the access to and maintenance of power. If government is able to collect data on its citizens both by demanding that they transact with them online - 'digital by default' is the position of the UK Government (GCS, 2015) - and by having budgets large enough to allow them the resources to analyse big data, that then reproduces its institutionalised agency and further limits its citizens' access to it. This is doubly the case if the traditional protocols where information sharing between government, its departments, other public sector organizations and their agents and partners are recinded. Hence, for example, if health data is 
aggregated with benefit entitlement, policy decisions may be made purely on cost. Reduced cost could be a social net value, but the externality is that policy decisions are made in such a way that parties to whom these are detrimental will not be able to negotiate with full knowledge of the impending disadvantages. Here too, then, engagement within the governance sphere becomes more costly for the individual and less costly for government.

The hegemony for government is further compounded by the current trend in certain government communication services. Their use of techniques to 'nudge' behavioral change (Thaler \& Sunstein, 2008) and the shift towards a campaigning mode of operating which is focused on delivering policy and not empowering citizens with information (Gregory, 2019), means that governments are less inclined to listen (Macnamara, 2016). If they do, it is instrumentally, that is to understand populations better so that they can be 'nudged' more easily and effectively.

The dangers inherent in governments obtaining too much knowledge and power over citizens is not new, neither is their ability to obtain that information. Totalitarian regimes have for centuries maintained large internal security forces to spy on and control their own citizens and set up infra-structures where citizens and even members of the same family spy on each other. However, the value that online, personal interactions yield for government far outstrip anything that has ever existed in the past (Kobie, 2019; West, 2019).

\subsection{The Civic Sphere}

The civic sphere is the space in which the polyphony of civil society voices takes place and discourse about society's choices is enabled. Public relations that harvests big data may damage such polyphony and thus individuals' and communities' agency in the institutional logic of the civic sphere, i.e., in participation. The concern of the authors of this paper and others (Bourne, 2019; Collister, 2015) is about the externality created by those with the hegemonic influence over the public sphere, notably corporations, government, NGOs and the media. 
There are many areas that could be identified as concerning in the civic sphere, but just two are focused on here. Firstly, concerns regarding the use of algorithms to rank the topics for public debate based on what is gleaned about individuals' preferences. There is substantial evidence that this is affecting the news agenda, with topics that are popular dictating the content of hard and soft copy publications rather than their importance or newsworthiness. Indeed, rather than journalists (and their proxies, public relations professionals) determining them and writing content, it is increasingly algorithms and bots. Thus, the public sphere can be put under hegemonic influence of organizations with the ability to conduct data-driven public relations at the expense of those groups in society without such ability. Their legitimate and potentially important voices may be missed or left unrepresented.

Secondly, 'micro-targeting' of citizens based on their previously submitted personal data can obscure society's full view on all the positions in a debate. The Trump campaign in 2016 produced around 50,000 versions of its advertisements daily and some were aimed at less than 100 voters in a particular district (The Economist , 4 November 2017). As a result, manipulation - the near complete destruction of agency and replacement by hegemony - can become easier as fake news and insinuations remain uncontested and create infamous social media bubbles, like the 'fachosphere' in France and the 'Paralleluniversum' in Germany.

\section{Remedies}

If data-driven public relations produces and reproduces hegemony on one side and negative externalities on the other, an ethical debate is in order. However, there is little reflection in the public relations academy on the ethics of big data (Bachmann, 2019; Buhmann, 2019). This paucity is typically attributed to the lagging of research and ethical deliberations behind technological progress (Nunan \& DiDomenico, 2013; 2017; Boyd \& Crawford, 2012; DeGeorge, 2003). Laudable exceptions (Hong \& Thong 2013; Bambauer 2014; Bateman et al. 2013) focus on dysfunctions, or on what Nunan and DiDomenico (2017) call 
'normal accidents'. However, the authors of this article posit that the externalities described are not accidents, but constitutive of big data-driven public relations.

Economics offers two major remedy types against externalities. Both are investigated here to determine if they provide remedies against the damage caused by big data-driven public relations.

There is firstly the concept of 'Pigovian taxes', i.e. the corrective intervening into a price of a good via taxation (Pigou, 1920). This form of intervention is typically deemed to be especially effective when combatting instances in which a private/commercial net product and a social net product diverge, as is currently the case for the use of big data in public relations as described here. When private contractual arrangements (between data-aggregating organizations and data-supplying individuals) will not resolve the externalities, then government intervention via taxes becomes legitimate and necessary in the eyes of Pigovian taxes' proponents (Knight, 1924; Young, 1928; Sraffra 1926; Clapham 1922). The idea is that by introducing a tax (equal to the marginal social cost of data aggregation) on each transaction between data-aggregating organizations and data-supplying individuals, prices for their data supply will go up, thus forcing organisations to internalise the social cost of data aggregation. Such taxes, e.g. on plastic bags (in India), on car ownership (in Singapore), on carbon production (in Denmark) make consumption more expensive and thus reduce externalities such as pollution.

A pre-internet example by Meade (1952) has strong parallels to big data-driven public relations today: the nectar in apple blossoms can be considered as input into the aggregation of honey, but one that is used by beekeepers without paying apple farmers. Here, the concept of 'Pigovian taxes' calls for such unpaid input (nectar/individual data) to be priced and taxed. Moreover, proponents hope those taxes create a 'double dividend': on top of creating social benefits by pricing in harmful externalities, they raise society's revenues (in taxes) that can then be invested into social net product. 
However, precisely because taxation requires that a production input have a price to begin with, this form of intervention will not address the ethical challenges around big data, because the supply of individual data is already happening 'for free' and is thus neither price-, nor taxable.

There is secondly, the 'Coase-theorem' as an alternative possible remedy. To its proponents (Coase, 1960, 1988, 1995; Anderson \& Leal, 2001; Anderson \& McChesney 2003; Stigler, 1966), externalities are predominantly the result of illdefined property rights: there is no 'atmosphere', i.e., the apple farmers own the nectar just as individuals own their data, and both should be enabled to price and trade them. The rights (e.g. to nectar, or to personal data) should be better assigned so that input suppliers would be able to 'sell' these at a price negotiated with the buyer, e.g. with bee-keepers or data-aggregating organisations. These property rights need to therefore be assigned by property rules commonly found in private law.

At first sight, the Coase-theorem seems better suited to address the ethical challenges of the big data-driven public relations. The theorem conceptually sidesteps the problem of a production input (i.e., an individual's data) not being priced. However, it too is unsuitable given the size of today's big data public relations industry. There exist no international polities that can design, let alone enforce boundary spanning data-property rights of consumer-citizens, attempts by EU notwithstanding (O’Neil, 2016: 214). The same reasoning lies behind the limited value of the Coase-theorem when trying to avoid environmental damage: the ecosystem cannot be subdivided into individually held areas, each protected by property rights.

Furthermore, any solution based on the Coase-theorem would require that consumer-citizens organize themselves, coordinate their interests, agree on a negotiation process, bargain with hegemonic organizations, and then formulate contracts for the sale and aggregation of their personal data. This is not feasible. As described by its proponents (Baumol \& Oates, 1975), people are prevented 
from negotiating such a solution with the buyers when "(i) the asset whose use gives rise to external effects is a public good, and (ii) a large number of persons are involved" (Barnett \& Yandle, 2009, p. 144) as this would make the cost of negotiating far higher than the benefit for the individual and society. This is precisely the case for big data driven public relations. The Coase-theorem therefore also offers no remedy to externalities of big-data driven public relations.

Because these externalities can not be addressed with traditional concepts, the remediation of hegemony and the restoration of agency needs to be placed at the centre of a broader debate about 'hegemony 2.0' in public relations. This is not as radical a plea as it sounds. Nobel laureates have successfully called for interventions into other markets that would otherwise have been equally fraught with social costs (Ostrom, 1990; Stiglitz, 2002, 2006). Also, specific interventions, especially in the organization of information have had major impacts on markets (e.g. for labour, stocks, bonds, microcredits, sharecropping) and societies (Akerlof \& Yellen, 1985a, 1985b; Stiglitz, 2000) before.

Similarly, the authors propose that the most prevalent social costs of big datadriven public relations can be addressed if at least five forms of interventions are debated:

1) Consumer-citizens are given choices about whether, how, where and when they want their data to be stored, used, repurposed, or traded. New technologies such as blockchain allow control over the information pipeline. Other new technologies such as the new smart web operating system Elastos, aims to create a whole ecosystem of distributed applications (DApps) which are not owned centrally or by a third party, not copiable and not connected to the internet by default, This allows citizens to hold their own data and only release what they decide is appropriate, to whom, when and where. It is perfectly possible for individuals to create a repository of their data which they are prepared to allow public access to similar to that available on public electoral 
registers. Thus, say, at one level data such as name, address, age (if not data of birth), job title, place of work etc. could be accessed by anyone. Additional repositories or single pieces of data at higher levels containing more personal information such as date of birth, hobbies, make of car etc, could also be specifically purposed and released upon request. It is plausible to envisage a whole variety of such repositories being held by individuals.

Likewise, it is possible to envision individual or hierarchies of permissions to aggregate personal data with other information being built. For example, no aggregation allowed, allowing aggregation with one other data set (for example purchasers of the same product) and so on. An additional condition on using this data aggregation would be to share the results with the data owner if they so wished. Thus, aggregators would pay a 'price' for data in terms of returning agency over personal data to owners, seeking positive permissions to allow access to it, and sharing the interpreted results and thereby addressing information asymmetry. In the case of the current data harvesting technologies used by companies such as Amazon, Alibaba and Google where data is kept and aggregated by them and others with neither the data owners' permission nor full knowledge of how the information is being used, four more interventions are recommended:

2) Consumer-citizens should be made fully aware of any interaction involving their data in cases where that interaction is actually a market transaction and contributes to the input production for big data-driven public relations. The practical implications of this recommendation, are of course enormous for the supplier of data, who could be swamped with notifications and for the receiver of that data who would have to put in place tracking systems and reporting procedures which will be cumbersome. In fact, the current system would be likely to collapse and therefore these companies would have to find new ways of engaging with customers that allows the latter to retain agency over their data and empowers them to dictate that a less cumbersome system of permissions to be instigated. In time the system would become self-regulating even if 
it could well severely limit data aggregation and analytics in public relations in the short-term. In the view of the authors of this article, that could be a good development since the purpose is to give the datasuppliers agency over their own data and to provide them with the information they need to make informed decisions. A further ethical benefit is that it would put a brake on the current pervasive system which is predicated on information asymmetry, and would allow time for an informed debate to take place.

3) Individuals are made aware of how their data is being aggregated and with what. For example, if it is being combined with facial recognition data, or personality profiling materials.

4) The material and intelligence value of such transactions are disclosed, including the monetary value of their data to public relations conducting organisations and the marginal social cost to society of collecting and trading those data. The monetary value should be shared with the supplier. This is perfectly possible now with micro-financial transaction software.

5) The choices and the transactions based on those choices remain reversible and online traces are removed if they are reversed.

In the market for big data there are already examples of these interventions. However, none of these have been developed or deployed in the public relations industry. Examples include movements to audit or at least identify the algorithms behind the collection and use of data, e.g. the Web Transparency and Accountability Project at Princeton University, or the Message Machine at ProPublica, a think-tank. The Open Algorithms project (OPAL) whose collaborators include Orange, the MIT Media Lab, the Data-Pop Alliance, Imperial College and the World Economic Forum examines how data platforms can aggregate large data sets for social good by asking specific permissions from individuals for specific information relating to specific projects.

The reduction of hegemony is also prevalent in the nascent peer-to-peer lending industry where businesses like Lending Club and Prosper make their credit 
scoring algorithms visible to lenders (unlike traditional banks), or in the 'Honest Ads Act' introduced by a group of US senators in which organizations using social media in their communication would be required to divulge to netizens which user classification made them see an advertisement.

\section{Conclusions}

Reflecting in an earlier decade about the hegemonic nature of public relations, Holtzhausen (2000: 96) comments that '[a]s a social science that has the ability to influence the very basis of society and civilization, it is impossible for public relations to escape scrutiny of its effects on postmodern society'. This article has attempted to demonstrate that such scrutiny of public relations is overdue after the rise of big data. The authors argue that the social costs need to be understood as market- and society-wide externalities and be treated as such by society. Public relations needs to lead, inter alia by debating at least the five possible interventions to protect and restore agency for consumer-citizens, communities and society when it interacts with these stakeholders

Given its embedded position as an interlocutor in all three spheres of society the public relations profession is ideally placed to be the instigator in this debate, bringing to the corporate, government and public agendas the issues outlined in this article. The ethical codes of most professional bodies of public relations have within them the duty to serve society as well as clients and employers. It is not enough for professionals to be adroit users of the products and possibilities that big data offer. It is incumbent on public relations to ask deeper questions about what sort of society and organizations it helps create via the production, reproduction and use of big data. 
References

Akerlof, G.A. (1970). The market for lemons: quality uncertainty and the market mechanism. Quarterly Journal of Economics, 84, 488-500.

Akerlof, G.A. (2000). Behavioral macroeconomics and macroeconomic behavior. American Economic Review, 92, 411-433.

Akerlof, G.A. \& Yellen, J.L. (1985a). A near rational model of the business cycle, with wage and price inertia. Quarterly Journal of Economics, 100, 823-838.

Akerlof, G.A. \& Yellen, J.L. (1985b). Can small deviations from rationality make significant differences to economic equilibria? American Economic Review, 75, 708-720.

Anderson, T.L. \& Leal, D.R. (2001). Free Market Environmentalism. New York: Palgrave.

Anderson, T.L. \& McChesney, F.S. (2003). Property Rights: Cooperation, Conflict, and Law. Princeton: Princeton University Press.

Annenberg Center for Public Relations. (2019). 2019 Global Communications Report. PR: Tech. The future of technology in Communications. USC Annenberg Centre for Public Relations, University of Southern California. Available from https://annenberg.usc.edu/news/research-and-impact/usc-annenberg-studypredicts-technology-will-help-citizens-become-more

Argenti, P. (2013). Corporate communication (6th ed.). New York, NY: McGraw Hill. A.W. Page Society. The Page Authenticy System. Available at https://page.org/ Bambauer, D. (2014). Ghost in the network. University of Pennsylvania Law Review, 162, 1050.

Barnett, A.H. \& Yandle, B. (2009). The end of the externality revolution. Social Philosophy \& Policy Foundation, 26, 130-150.

Bateman, C., Valentine, S. \& Rittenburg, T. (2013). Ethical decision making in a peer-to-peer file sharing situation. The role of moral absolutes and social consensus. Journal of Business Ethics, 115, 229-240.

Baumol, W.J., \& Oates, W. (1975). The Theory of Environmental Policy. Englewood Cliffs: Prentice Hall.

Bloomberg Businessweek (2017). Linkedin's court battle with an HR startup will decide who gets to mine your online activity - and sell it to your boss. 20

November.

Bourne, C. (2019). AI cheerleaders: public relations, neo-liberalism and artificial intelligence. Public Relations Inquiry, 8(2), 109-125. 
Boyd, D. \& Crawford, K. (2012). Critical questions for big data: provocations for a cultural, technological and scholarly phenomenon. Information, Communication \& Society, 15, 662-679.

Britainthinks (2015). Life Offline: What life is like for older people who don't use the internet. A report prepared by on behalf of Age UK. May 2015.

Buhmann, A., Passman, J. \& Fieseler, C. (2019). Managing algorithmic accountability: Balancing reputational concerns, engagement strategies, and the potential of rational discourse. Journal of Business Ethics, Published on line June 2019. DOI:10.1007/s10551-019-04226-4 1-16

Centre for Retail Research (2019). Online: Britain, Europe \& North America. Available at https://www.retailresearch.org/online-retail.html

Centre for Retail Research (2018). Retail at Bay 2018. Available at https://www.retailresearch.org/retailatbay2018.php

Cerquitelli, T., Quercia, D. \& Pasquale, F. (2017). Transparent data mining for big and small data. Berlin: Springer.

Clapham, J.H. (1922). Of empty economic boxes. Economic Journal, 32, 305-314.

Coase, R.H. (1960). The problem of social cost. Journal of Law and Economics, 3, $1-44$.

Coase, R.H. (1988). The Firm, the Market, and the Law. Chicago: University of Chicago Press.

Coase, R.H. (1995). Essays on Economics and Economists. Chicago: University of Chicago Press.

Collister, S. (2015). Algorithmic public relations: Materiality, technology and power in a post-hegemonic world. In J. L'Etang, D. McKie, N. Snow \& J Xifra (Eds). The Routledge Handbook of Critical Public Relations. (pp 360-371). New York, NY: Taylor \& Francis.

Cornelissen, J. (2017). Corporate Communication. London: Sage.

DeGeorge, R. (2003). The ethics of information technology and business. Oxford: Blackwell Publishing.

Doward, J. \& Gibbs, A. (2017). Did Cambridge Analytica influence the Brexit vote and the US election? The Observer, $4^{\text {th }}$ March, 2017. Available from https://www.theguardian.com/politics/2017/mar/04/nigel-oakes-cambridgeanalytica-what-role-brexit-trump

Friedland, R., \& Alford, R. R. (1991). Bringing society back in: Symbols, practices and institutional contradictions. In W. W. Powell, \& P. J. DiMaggio (Eds.), The new institutionalism in organizational analysis. Chicago: University of Chicago Press. 
Flyverbom, M., Deibert, R. \& Matten, D. (2019). The governance of digital technology, big data, and the new roles and responsibilities for business. Business \& Society, 58(1) 3-19.

GCS, (Government Communication Service) (2015). Modern Communications Operating Model. Available from https://gcs.civilservice.gov.uk/wpcontent/uploads/2015/11/Modern-Comms-Team-Document FINAL-AW-V2.pdf

GCS, (Government Communication Service) (2019). Government Communication Plan 2019/20 https://gcs.civilservice.gov.uk/communication-plan-2019/wpcontent/uploads/2019/04/Government-Communication-Plan-2019.pdf

Galloway, C. \& Swiatek. L. (2018). Public relations and artificial intelligence: It's not (just) about robots. Public Relations Review, 44(5), pp 734-740.

Gramsci, A. (1971). Selections from the Prison Notebooks. New York: International.

Gregory. A (2019). UK Government Communication: the Cameron years and their ongoing legacy. Public Relations Review. Vol. 45, No. 2, pp. 202 - 216.

Halff, G. \& Gregory, A. (2014). Toward an historically informed Asian model of public relations. Public Relations Review, 40, 397-407.

Holtzhausen, D. (2000). Postmodern values in public relations. Journal of Public Relations Research, 12(1), 93-114.

Holtzhausen, D. (2002). Towards a postmodern agenda for public relations. Public Relations Review, 28, 251-264.

Holtzhausen, D. (2016). Datafication: threat or opportunity for communication in the public sphere? Journal of Communication Management. 20(1), 21 - 36.

Hong, W., \& Thong, J. (2013). Internet privacy concerns: An integrated conceptualization and four empirical studies. MIS Quarterly, 37, 275-298.

IDC (2019). Worldwide semi annual big data and analytics spending guide. Available at https://www.idc.com/getdoc.jsp?containerId=prUS44998419

L'Etang, J. (2005). Critical public relations: some reflections. Public Relations Review, 31, 521-526.

L'Etang, J., \& Pieczka, M. (Eds.) (1996). Critical perspectives in public relations. London: ITBP.

L'Etang, J., \& Pieczka, M. (Eds.) (2006). Public relations. critical debates and contemporary practice. Mahwah, NJ: Lawrence Erlbaum Associates.

Knight, F.H. (1924). Some Fallacies in the Interpretation of social cost. Quarterly Journal of Economics, 37, 582-606. 
Kobie, N. (2019). The complicated truth about China's social credit system. Wired. Available from https://www.wired.co.uk/article/china-social-creditsystem-explained.

Lepri, B., Oliver, N., Letouze, E., Pentland, A. \& Vinck, P. (2017). Fair, transparent and accountable algorithmic decision-making processes. Philosophy and Technology, 30(4), 1-17.

Lepri, B., Staiano, J., Sangokoya, D., Letouze E. \& Oliver, N. (2016). The tyranny of data? The bright and dark sides of data-driven decision-making for social good. In T. Cerquitelli, D. Quercia \& F. Pasquale (Eds.), Transparent data mining for big and small data, Studies in big data series, (pp 3-24). Cham, Switzerland: Springer.

Macnamara, J. (2016). Organizational listening: the missing essential in public communication. New York: Peter Lang.

McAffee, A. \& Brynjolfsson, E. (2012). Big data: the management revolution. Harvard Business Review, 90, 60-68.

Meade, J.E. (1952). External economies and diseconomies in a competitive situation. Economic Journal, 62, 54-67.

Naim, M. (2013). The end of power. New York: Basic Books.

Nunan, D., \& DiDomenico, M. (2013). Market research and the ethics of big data. International Journal of Market Research, 55, 2-13.

Nunan, D., \& DiDomenico, M. (2017). Big data: a normal accident waiting to happen? Journal of Business Ethics, 145, 481-491.

O’Neil, C. (2016). Weapons of Math Destruction. London: Penguin Books.

Ostrom, E. (1990). Governing The Commons: The Evolution Of Institutions For Collective Action. Cambridge: Cambridge University Press.

Palenchar, M.J., Heath, R.L, Levenshus, A., Lemon, L. (2017). Marketplace commodification of risk communication: consequences for risk bearers and implications for public relations. Public Relations Review, 43, 709-717.

Pigou, A.C. (1920). The Economics of Welfare. London: Macmillan Publishing.

Polonski, V. (2016). Would you let an algorithm choose the next U.S. president? TechCrunch, Nov 6, 2016.

Roper, J. (2005). Symmetrical communication: excellent public relations or a strategy for hegemony? Journal of Public Relations Research, 17(1), 69-86.

Rothschild, M., \& Stiglitz, J.E. (1976). Equilibrium in competitive insurance markets: An essay on the economics of imperfect information. Quarterly Journal of Economics, 90, 630-649.

Spence, A.M. (2002). Signaling in retrospect and the informational structure of markets. American Economic Review, 92, 434-459. 
Spence, A.M. (13 Jan. 2012). Mind over Market. Project Syndicate,

http://www.project-syndicate.org/commentary/mind-over-market

Sraffra, P. (1926). The laws of returns under competitive conditions. Economic Journal, 36, 535-550.

Stauber, J., \& Rampton, S. (1995). Toxic sludge is good for you! Lies, damn lies and the public relations industry. Monroe: Common Courage.

Stigler, G.J. (1966). The Theory of Price. London: Collier-Macmillan.

Stiglitz, J.E. (1975). The theory of screening, education and the distribution of income. American Economic Review, 65, 283-300.

Stiglitz, J.E. (2000). The contributions of the economics of information to twentieth century economics. Quarterly Journal of Economics, 115, 1441-1478.

Stiglitz, J.E. (2002). Globalization and its discontents. London: Penguin.

Stiglitz, J.E. (2006). Making globalization work. The next steps to global justice. London: Penguin.

Suresh, M (2016). Unplugged: How to live life off-line. Available at https://malavikasuresh.wordpress.com/2016/07/28/unplugged-how-to-livelife-offline/

Tett, G. (2017). How big data rewrote the political message. Financial Times/Magazine, September 30, p. 46.

Thaler, R.H., Sunstein, C. (2008). Nudge: Improving Decisions about Health, Wealth and Happiness. New Haven: Yale University Press.

Thornton, P. H., \& Ocasio, W. (2009). Institutional logics. In R. Greenwood, R. Greenwood, et al. (Eds.), The sage handbook of organizational institutionalism (pp. 99-129). London: Sage.

Van den Bergh, J. (2010). Externality or sustainability economics? Ecological Economics, 69, 2047-2052.

Van den Bergh, J. (2012). What is wrong with 'externality'? Ecological Economics, 74, 1-2.

Weiner, M. \& Kochar, S. (2016). Irreversible: the public relations big data revolution. Institute for Public Relations, Gainesville, Florida.

Wiesenberg, M., Zerfass, A. \& Moreno, A. (2017). Big data and automation in strategic communication. International Journal of Strategic Communication, 11(2), 95-114. 
West, S.M. (2019). Data capitalism: redefining the logics of surveillance and Privacy. Business \& Society. 58(1), 20-41.

Young, A.A. (1928). Increasing returns and economic progress. Economic Journal, $38,527-542$. 